\title{
ОСОБЕННОСТИ ЗАБОЛЕВАЕМОСТИ САХАРНЫМ ДИАБЕТОМ 1 ТИПА У ДЕТЕЙ, ПРОЖИВАЮЩИХ В БРЯНСКОЙ ОБЛАСТИ, В ДИНАМИКЕ ЗА 2014-2019 ГГ
}

\author{
Зурова С.В.
}

ГБУЗ «Брянская областная детская больница», Брянск

ЦЕЛЬ: изучить динамику структуры и особенностей заболеваемости сахарным диабетом 1 типа в детской популяции населения Брянской области.

МАТЕРИАЛЫ И МЕТОДЫ: проанализированы истории болезней и амбулаторные карты детей, наблюдавшихся в детской областной больнице г. Брянска за период 2014-2019 г. Расчеты заболеваемости и распространенности проведены на 100000 населения соответствующего возраста, определен 95\% доверительный интервал. Статистическая обработка проводилась с использованием критерия Стьюдента и пакета программ MS Office 2010. По общепринятым формулам рассчитывались основные статистические параметры: среднюю величину переменной — «М», ошибку средней — «m». В процессе анализа вывод о статистической значимости принимался при $p<0,05$.

РЕЗУЛЬТАТЫ: в Брянской области отмечен полуторакратный относительно 2013 г. рост $(\mathrm{r}=0,98)$ распространенности сахарного диабета 1 типа среди детского населения на фоне слабого прироста заболеваемости $(r=0,34)$. Средний за период показатель заболеваемости СД 1 составил 25,25 на 100000 (95\% ДИ 20,8-31,5), с пиком в 2019 г. Стабильно наибольшая частота заболеваемости сахарного диабета 1 типа у детей в возрасте 5-9 лет. Отмечается появление патологии в возрастной группе до года и увеличение доли детей 10-14 лет ( $<<0,05)$, при этом снижение первичной заболеваемости среди детей 15-17 лет $(p<0,05)$. Достоверного изменения динамики манифестации СД 1 у детей с возрастных группах 1-4 года и 5-9 лет не выявлено ( $r=0,096$ и $r=0,22$ соответственно). Гендерных отличий заболеваемости СД 1 у детей, в том числе у лиц юношеского возраста (15-17 лет) не выявлено ( $<<0,05)$. Установлено, что наибольшее число случаев заболевания СД1 у детей наблюдается осенью и весной, с пиком в октябре (11,5\%) и в марте (12\%) соответственно, а также в августе (11,5\%). Наименее насыщенными по манифестации СД 1 у детей отмечены май (4,8\%), июнь (6\%) и июль (2\%). Заболеваемость у мальчиков по сравнению с девочками значимо была выше с октября по январь на протяжении всех шести лет ( $<<0,05)$. За выбранный период в 14,4\% $(95 \%$ ДИ 8-21) случаях первичной заболеваемости отмечена наследственная предрасположенность по СД1. Достоверно выше выявление случаев СД1 у отца $(p<0,5)$, также отмечено превышение наследственности по СД1 по мужской линии (64\%) над женской (36\%). За анализируемый период времени СД1 у детского населения манифестировал с кетоацидозом в 54\% случаев (95\% ДИ 40-65). Наиболее часто выявлялся СД1, осложненный кетоацидозом, у детей до года (100\%) и группы 5-9 лет - 49\% (95\% ДИ 30-71); далее шли группы 10-14 лет - 46\% (95\% ДИ 29-60), 1-4 года - 42\% (95\% ДИ 21-76), и 15-17 лет - 21\% (95\% ДИ 0-70). В группе 15-17 лет с 2017 по 2019 гг. не выявлено ни одного случая манифестации СД1 с кетоацидозом. Отмечена слабая тенденция снижения доли первичного СД1, осложненного кетоацидозом $(\mathrm{r}=0,39)$.

Выводы: продолжается слабый рост заболеваемости СД1 у детей Брянской области. Структура заболеваемости претерпевает изменения. Распространенность и заболеваемость СД1 в детской популяции Брянской области выше, чем в соседних регионах и в целом по стране (при сравнении полученных данных с данными Федерального регистра СД). Факторы, способствующие развитию СД1 у детей могут иметь особенности в зависимости от региона и требуют глубокого изучения.

КЛЮЧЕВЫЕ СЛОВА: заболеваемость СД1 у детей; сезонность; наследственность; кетоацидоз. 